\title{
Pemaknaan Peserta Didik Tentang Kecerdasan Spiritual
}

\author{
Salim Korompot, Sultan M Tarmizi Korompot \\ Universitas Negeri Gorontalo, SMA Negeri 3 Gorontalo Utara \\ salimkorompot@ung.ac.id, korompot2402@gmail.com
}

Received: 23 Februari 2020; Revised: 27 April 2020; Accepted: 28 April 2020

DOI: http://dx.doi.org/10.37905/aksara.6.2.171-180.2020

\begin{abstract}
ABSTRAK
Salah satu diantara beberapa kompetensi yang dikembangkan dalam kehidupan peserta didik adalah kecerdasan spiritual. Penelitian untuk mendeskripsikan pemakanan peserta didik tentang kecerdasan spiritual. Penelitian ini menggunakan pendekatan deskripsi kuantitatif, pengumpulan data menggunakan angket dan analisis data menggunakan analisis persentase. Hasil penelitian menunjukkan bahwa peserta didik kurang baik dalam memakanakan kecerdasan spiritual dalam kehidupan sehari-hari, meliputi pemaknaan bersifat fleksibel, memaknakan memiliki kesadaran (self-awareness) yang tinggi, pemaknaan kemampuan untuk menghadapi penderitaan dan mengambil hikmah darinya, pemaknaan kemampuan untuk menghadapi dan mengatasi rasa sakit, pemaknaan memiliki kualitas hidup yang diilhami oleh visi dan nilai-nilai, pemaknaan enggan melakukan sesuatu yang menyebabkan kerugian atau kerusakan, pemaknaan cenderung melihat hubungan antar berbagai hal berbeda menjadi suatu yang holistik, pemaknaan cenderung untuk bertanya "mengapa" atau "apa" dan mencari jawaban-jawaban yang fundamental, dan pemaknaan bertanggungjawab untuk menebarkan visi dan nilai-nilai kepada orang lain dan menunjukkan cara menggunakan. Guna mengoptimalkan pemaknaan peserta didik dalam kecerdasan spiritual, dapat dilakukan melalui pendekatan bimbingan dan konseling, serta mengatur dalam bentuk manajemen peserta didik berbasis kecerdasan spiritual.
\end{abstract}

Kata Kunci: pemaknaan, peserta didik, kecerdasan spiritual

\section{PENDAHULUAN}

Pendidikan dalam Undang-Undang Nomor 20 Tahun 2003, disebutkan sebagai usaha sadar dan terencana untuk mewujudkan suasana belajar dan proses pembelajaran agar peserta didik secara aktif mengembangkan potensi dirinya untuk memiliki kekuatan spiritual keagamaan, pengendalian diri, kepribadian, kecerdasan, akhak mulia, serta keterampilan yang diperlukan dirinya, masyarakat, bangsa dan Negara. Hal ini menegaskan bahwa pendidikan merupakan sebuah sistem interaktif yang komprehensip dalam rangka mewujudkan peserta didik yang memiliki berbagai kompetensi yang diperlukan dalam kehidupan. Salah satu diantara beberapa kompetensi yang dikembangkan dalam kehidupan peserta didik tersebut adalah kekuatan spiritual keagamaan. Secara konseptual antara spiritual dengan religiusitas memang memiliki dinamika pandangan dan pemahaman. Kecerdasan spiritual bukan doktrin agama yang mengajak umat manusia untuk cerdas dalam memilih atau memeluk salah satu agama yang dianggap benar, namun kecerdasan spiritual lebih merupakan konsep yang berhubungan dengan bagaimana seseorang cerdas dalam mengelola dan 


$\begin{array}{ll}\text { Volume } & : 06 \\ \text { Nomor } & : 02 \\ \text { Bulan } & : \text { Mei } \\ \text { Tahun } & : 2020 \\ \text { http } & : / / \text { jurnal.pps.ung.ac.id/index.php/AKSARA/index }\end{array}$

mendayagunakan makna-makna, nilai-nilai, dan kualitas-kualitas kehidupan spiritualnya (Akhirin, 2013). Kim dkk, dalam hal ini menganggap religiusitas dan spiritualitas merupakan konsep yang sama, sementara Ivtzan Chan, Gardner dan Prashar menganggap keduanya merupakan konsep yang berbeda (Amir \& Lesmawati; 2016;67). Meskipun demikian, jika ditelusuri secara hakikat, terdapat benang merah antara spiritualitas dan religiusitas, bahkan kedua istilah ini sering dipertukarkan penggunaannya baik sebagai sebuah istilah maupun secara pemaknaan (Imaduddin, 2017;4).

Kecerdasan spiritual merupakan anugerah yang dimiliki oleh setiap manusia, perempuan, laki-laki, baik orang tua, dewasa maupun remaja. Perbedaannya adalah pada kemampuan masing-masing untuk memaknai dengan baik kehidupan spiritualnya dalam setiap aktivitas hidup sehari-hari. Banyak orang yang dapat mengekspresikan kecerdasan spiritual melalui agama, tetapi keberagamaan seseorang tidak menjamin tingginya kecerdasan spiritual (Yusuf \& Nurihsan, 2013;243). Demikian halnya dengan seorang peserta didik di sekolah, bahwa dengan adanya kecerdasan spiritual, maka peserta didik akan mampu menjalani proses pendidikannya di sekolah lebih teratur dan tertata sesuai dengan harapan dari berbagai pihak, baik pihak sekolah itu sendiri ataupun dari pihak orang tua dan masyarakat secara umum.

Peserta didik yang memiliki kecerdasan spiritual diantaranya memiliki visi dalam melaksanakan aktifitasnya demi cita-cita yang ingin diwujudkan, Ia tidak melakukan halhal yang merugikan selalu mengikuti aturan-aturan yang ada di sekolah. Hasil penelitian Rampisela dkk (2017) menyatakan bahwa terdapat hubungan kecerdasan emosional dan kecerdasan spiritual dengan prestasi belajar siswa di SMP Katolik ST. Fransiskus Pineleng. Basuki $(2015 ; 132)$ menyimpulkann penelitiannya bahwa terdapat pengaruh langsung yang signifikan kecerdasan spiritual terhadap motivasi belajar, dan terdapat pengaruh langsung yang signifikan kecerdasan spiritual terhadap prestasi belajar matematika. Hasil wawancara pada peserta didik menunjukkan beberapa perilaku yang tidak sesuai dengan ciri-ciri individu yang memiliki kecerdasan spiritual yang baik. Hal itu menyebabkan sebagian peserta didik kurang peduli dengan pembelajaran yang ada di sekolah, mereka lebih banyak menghabiskan waktu di luar kelas dibandingkan berada di dalam kelas. Dengan demikian perlu melakukan pemahaman yang mendalam mengenai pemaknaan peserta didik tentang kecerdasan spiritual.

\section{KAJIAN TEORI \\ KECERDASAN SPIRITUAL}

Baharuddin \& Wahyuni (2015: 220 - 221), mengartikan kecerdasan spiritual sebagai kecerdasan ruhaniah, kecerdasan hati, dan kecerdasan jiwa. Ia adalah kecerdasan yang dapat membantu manusia menyembuhkan dan membangun diri secara utuh. Kecerdasan spiritual adalah inti kecerdasan manusia, kecerdasan ini membuat manusia mampu menyadari siapa dirinya sesungguhnya (Akhirin, 2013). Lebih dari itu, Nisa $(2009 ; 73)$ memaknai kecerdasan spiritual merupakan landasan yang diperlukan untuk memfungsikan kecerdasan intelegensi (IQ) dan kecerdasan emosional (EQ) secara efektif, bahkan kecerdasan spiritual sama sekal tidak menafikan jenis kecerdasan yang lain, tetapi meningkatkan kualitasnya sehingga mencapai tingka "the ultimate meaning" atau kecerdasan sempurna. Dalam arti lain bahwa kecerdasan spiritual membawa manusia pada kondisi yang sangat ideal, memiliki berbagai kemampuan untuk membentuk diri yang utuh guna mencapai kesempurnaan. 
Spiritual intelligence increases an individual's capacity to understand others at a higher level. Spiritual understanding allows an individual to discern both the 'true cause' of behaviour without judgment, and serve the 'true needs' of others until they themselves learn to meet their own needs (Chin, dkk, 2011;3). Spiritual intelligence empowers the individual to cope with and resolve life-world issues while demonstrating virtuous behavior such as humility, compassion, gratitude, and wisdom (Howard, dkk, 2009;56). Zohar and Marshall, introduce the concept of spiritual intelligence (SI) as a form of intelligence that is based on a person's deepest meanings and needs to fulfill a higher existential purpose (dalam, Rahman \& Shah, 2015).

Kecerdasan spiritual adalah kemampuan yang dimiliki seseorang untuk menghadapi dan memecahkan berbagai makna, kontrol diri, dan menggunakan hati nuraninya dalam kehidupan serta mampu memberi makna nilai ibadah kehidupannya agar menjadi manusia yang sempurna atau insan kamil agar tercapai kehidupan dunia akhirat (Hera, 2017). Al Haddar (2016;43) menegaskan, pada dasarnya di antara tiga kecerdasan yakni IQ, EQ dan SQ, ada satu kecerdasan yang tertinggi yakni kecerdasan spiritual. SQ merupakan landasan yang diperlukan untuk memfungsikan IQ dan EQ secara efektif. SQ merupakan kecerdasan tertinggi yang mengintegrasikan semua kecerdasan di atas dan menjadikan manusia sebagai makhluk yang benar-benar utuh secara intelektual, emosional dan spiritual.

\section{MAKNA DAN CIRI KECERDASAN SPIRITUAL}

Pada awal 1990-an Persinger dkk menemukan keberadaan "God Spot” pada otak manusia. "God Spot" ini tidak membuktikan eksistensi Tuhan, tetapi menunjukkan bahwa otak telah mengembangkan atau menjawab permasalahan puncak/akhir (ultimate question), untuk memiliki atau menggunakan kepekaan terhadap makna dan nilai yang lebih luas (Yusuf dan Nurihsan 2013: 244). Hagar (2019) berpendapat bahwa kecerdasan spiritual merupakan kemampuan jiwa yang digunakan untuk mengenal keberadaan kita sebagai manusia untuk hidup di dunia dan posisi manusia sebagai seorang hamba di hadapan Allah, kecerdasan spiritual berbicara tentang kenapa manusia hidup di dunia. Baharuddin \& Wahyuni (2015: 221), menegaskan bahwa titik kekuaan kecerdasan spiritual sebenarnya terletak pada berkembangnya dengan baik jiwa dan hati manusia. Dua esensi manusia itu apabila dikembangkan maka akan mencapai tingkat ketajaman "mata hati",satu-atunya elemen esensi manusia yang sanggup menatap bayanaganbayangan tuhan yang diisyaratkan oleh alam semesta. Secara khusus Yusuf \& Nurihsan (2013;242) menjelaskan makna kecerdasan spiritual adalah kemampuan untuk (1) mengenali dan memecahkan masalah-masalah yang berkaitan dengan makna dan nilai, (2) menempatkan berbagai kegiatan dan kehidupan dalam konteks yang lebih luas, kaya dan memberikan makna, dan (3) mengukur atau menilai bahwa

Akhirin (2013) memaparkan ciri-ciri kecerdasan spiritual yakni kemampuan bersikap fleksibel (adaptif secara spontan dan aktif), tingkat kesadaran yang tinggi, kemampuan untuk menghadapi dan memanfaatkan penderitaan, kemampuan untuk menghadapi dan melampaui rasa sakit, kualitas hidup yang diilhami oleh visi dan nilainilai, keengganan untuk menyebabkan kerugian yang tidak perlu, kecenderungan untuk melihat keterkaitan antara berbagai hal (berpandangan holistik), kecenderungan untuk bertanya "mengapa" atau "bagaimana jika" untuk mencari jawaban-jawaban yang mendasar, kenjadi apa yang disebut psikolog sebagai bidang mandiri yaitu memiliki 


$\begin{array}{ll}\text { Volume } & : 06 \\ \text { Nomor } & : 02 \\ \text { Bulan } & : \text { Mei } \\ \text { Tahun } & : 2020 \\ \text { http } & : / / \text { jurnal.pps.ung.ac.id/index.php/AKSARA/index }\end{array}$

kemudahan untuk melawan konvensi. Selaras dengan ciri di atas, Yusuf dan Nurihsan $(2013 ; 244)$ memberikan penjelasan tentang individu yang memiliki kecerdasan spiritual tinggi, yakni bersifat fleksibel (mampu beradaptasi secara aktif dan spontan), memiliki kesadaran (self-awareness) yang tinggi, memiliki kemampuan untuk menghadapi penderitaan dan megambil hikmah darinya, memiliki kemampuan untuk menghadapi dan mengatasi rasa sakit, memiliki kualitas hidup yang diilhami oleh visi dan nilai-nilai, enggan melakukan sesuatu yang menyebabkan kerugian atau kerusakan, cenderung melihat hubungan antar berbagai hal yang berbeda menjadii suatu yang holistik, cenderung untuk bertanya "mengapa" atau "apa" dan mencari jawaban-jawaban yang fundamental, bertanggung jawab untuk menebarkan visi dan nilai-nilai kepada orang lain dan menunjukkan cara menggunakannya

\section{METODE PENELITIAN}

Penelitian ini menggunakan metode deskriptif kuantitatif. Penelitian ini dilaksanakan di SMA Negeri 1 Tapa, Kabupaten Bone Bolango, dengan indikator: bersifat fleksibel, emiliki kesadaran (self-awareness) yang tinggi, memiliki kemampuan untuk menghadapi penderitaan dan mengambil hikmah darinya, memiliki kemampuan untuk menghadapi dan mengatasi rasa sakit, memiliki kualitas hidup yang diilhami oleh visi dan nilai-nilai, enggan melakukan sesuatu yang menyebabkan kerugian atau kerusakan, cenderung melihat hubungan antar berbagai hal yang berbeda menjadi suatu yang holistic, cenderung untuk bertanya "mengapa" atau "apa" dan mencari jawabanmjawaban yang fundamental, dan bertanggung jawab untuk menebarkan visi dan nilai-nilai kepada orang lain dan menunjukkan cara menggunakannya.

Populasi dan sampel 100 orang, dengan teknik pengumpulan data menggunakan angket yang telah dilakukan uji validitas dan reliabilitas angket, dengan menggunakan pengukuran skala likert. Uji validitas menggunakan rumus Product Moment berikut ini:

$r_{x y}=\frac{n \cdot\left(\sum_{\mathrm{xy}}\right)-\left(\sum_{\mathrm{x}}\right)\left(\sum_{\mathrm{y}}\right)}{\left.\sqrt{\left\{n \cdot \sum x^{2}\right.}-\left(\sum x\right)^{2}\right\}\left\{n \sum^{2}-\left(\sum Y\right)^{2}\right\}}$

Uji Realibilitas instrumen ini menggunakan metode Alpha, dengan rumus:

$$
r=\left[\frac{k}{(k-1 S)}\right]\left[1-\frac{\sum S_{i}}{\sum S_{t}}\right]
$$

Berdasarkan hasil perhitungan reliabilitas instrumen, ddengan nilai $r$ tabel $n=100$ dan taraf signifikannya adalah 0,361, maka di dapat nilai reliabilitas instrument $(r)=$ $0,926>r$ tabel $=0,361$ perbandingan ini menunjukan hasil yang signifikan atau dapat dipercaya. Analisis data mmenggunakan teknik analisa persentase dengan menggunakan dengan formulasi: $\mathrm{p}=\mathrm{f} / \mathrm{n} \times 100 \%$ klasifikasi hasil analisis data adalah baik $(76 \%-100 \%)$, cukup baik (56\% - 75\%), kurang baik (40\%-55\%0 dan tidak baik (0 - 39\%).

\section{HASIL PENELITIAN DAN PEMBAHASAN}

Hasil penelitian dan pembahasan pemaknaan peserta didik tentang kecerdasan spiritual ini, dipaparkan dalam bentuk grafik dan disesuaikan dengan indikator yang telah ditetapkan, yakni: bersifat fleksibel, memiliki kesadaran (self-awareness) yang tinggi, memiliki kemampuan untuk menghadapi penderitaan dan megambil hikmah darinya, memiliki kemampuan untuk menghadapi dan mengatasi rasa sakit, memiliki kualitas hidup yang diilhami oleh visi dan nilai-nilai, enggan melakukan sesuatu yang 
menyebabkan

kerugian

atau

kerusakan, cenderung melihat hubungan antar berbagai hal yang berbeda menjadi suatu yang holistic, cenderung untuk bertanya "mengapa" atau "apa" dan mencari jawaban-jawaban yang fundamental, bertanggung jawab untuk menebarkan visi dan nilai-nilai kepada orang lain dan menunjukkan cara menggunakannya.

Grafik 1. Bersifat fleksibel

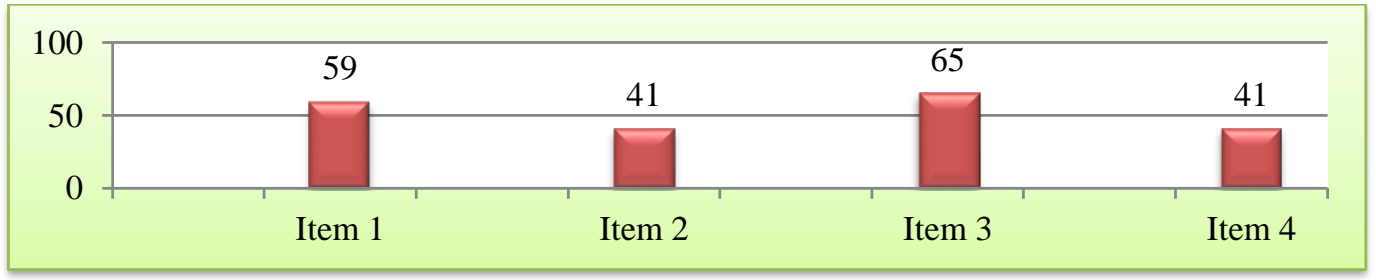

Berdasarkan Grafik 1. dapat dilihat bahwa nilai rata-rata peserta didik adalah 52\%, hal ini mengartikan, bahwa peserta didik kurang baik memaknakan bersifat fleksibel dalam kehidupan sehari-hari. Item 1 menandai 59\% peserta didik sulit menyesuaikan diri saat sedang bermain bersama, item 2 menandai $41 \%$ peserta didik selalu datang tepat waktu, item 3 menandai bahwa $65 \%$ peserta didik sulit memahami setiap mata pelajaran, dan item 4 menandai $41 \%$ peserta didilk cepat mengerti setiap pelajaran yang guru ajarkan. Dalam makna lain, bahwa sebagian (52\%) peserta didik dapat bersifat fleksibel, dan sebagian (48\%) tidak dapat bersiat fleksibel dengan baik, yang ditandai dengan sulit menyesuaikan diri saat sedang bermain bersama, jarang datang tepat waktu, sulit memahami mata pelajaran, dan kurang cepat mengerti setiap pelajaran yang guru ajarkan.

Grafik 2. Memiliki kesadaran (self awareness) yang tinggi

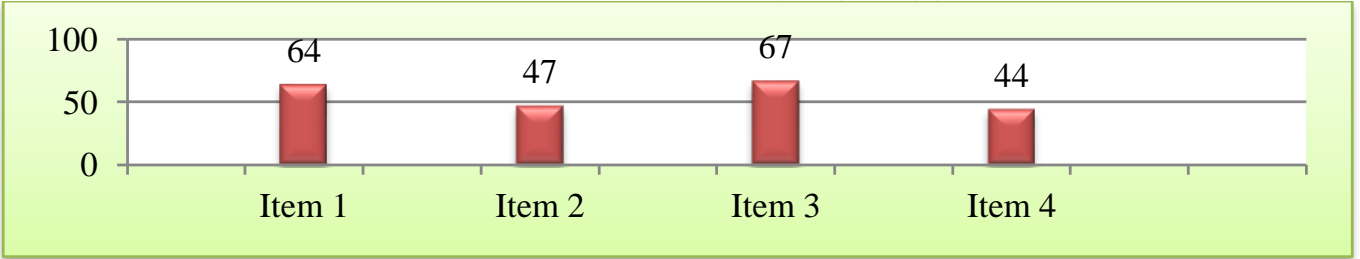

Berdasarkan Grafik 2, dapat dilihat bahwa nilai rata-rata peserta didik adalah 56\%, hal ini mengartikan bahwa peserta didik cukup baik dalam memaknakan memiliki kesadaran (self awareness) dalam kehidupan sehari-hari. Item 1 menandai 64\% peserta didik membantu membersihkan lingkungan rumah, item 2 menandai $47 \%$ peserta didik selalu berusaha memahami apa yang diinginakan orang tua, item 3 menandai bahwa $67 \%$ peserta didik peduli dengan orang lain, dan item 4 menandai $44 \%$ peserta didik ketika pulang sekolah selalu menjabat tangan orang yang ada di rumah. Dalam arti lain, bahwa data memiliki kesadaran (self-awareness) yang tinggi berbeda dengan sebelumnya. Peserta didik cukup baik (56\%) dalam memaknainya, seperti membantu membersihkan lingkungan rumah, selalu berusaha memahami apa yang diinginakan orang tua, peduli dengan orang lain, dan ketika pulang sekolah selalu menjabat tangan orang yang ada di rumah. 
Grafik 3. Memiliki kemampuan untuk menghadapi penderitaan dan mengambil hikmah darinya

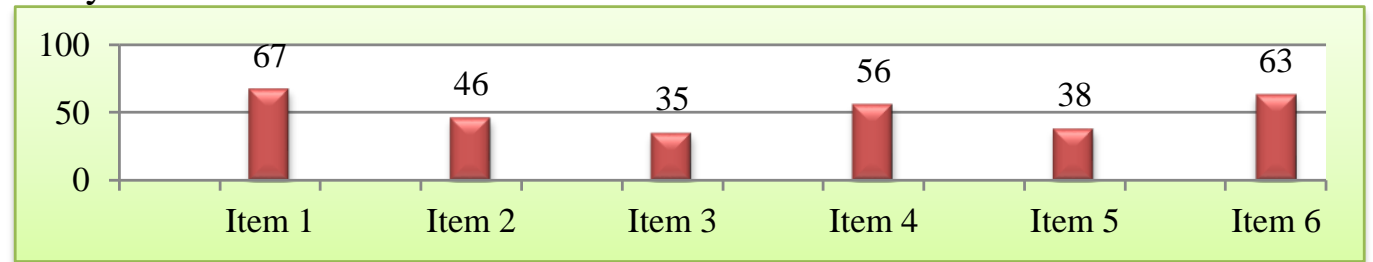

Berdasarkan Grafik 3, dapat dilihat bahwa nilai rata-rata peserta didik adalah 51\%, hal ini mengartikan bahwa peserta didik kurang baik dalam memaknakan memiliki kemampuan untuk menghadapi penderitaan dan mengambil hikmah darinya. Item 1 menandai $67 \%$ peserta didik sering mengeluh dengan hidupnya, item 2 menandai $46 \%$ peserta didik selalu berusaha bangkit disetiap gagal, item 3 menandai bahwa $35 \%$ peserta didik berusaha dan mengambil makna bila nilai tidak memuaskan, item 4 menandai $56 \%$ peserta didik malu dengan kehidupan yang serba sederhana, item 5 menandai 38\% peserta didik menganggap kegagalan itu adalah awal meraih keberhasilan, dan item $63 \%$ peserta didik akan sangat marah bila guru menghukumnya. Dalam artian bahwa peserta didik kurang baik (51\%) dalam memaknai kemampuan untuk menghadapi penderitaan dan mengambil hikmah darinya dalam kehidupan sehari-hari. Peserta didik sering mengeluh dengan hidupnya, kurang mampu bangkit mengahadapi kegagalan, merasa malu dengan kehidupan yang serba sederhana, marah bila guru menghukumnya.

Grafik 4. Memiliki kemampuan untuk menghadapi dan mengatasi rasa sakit

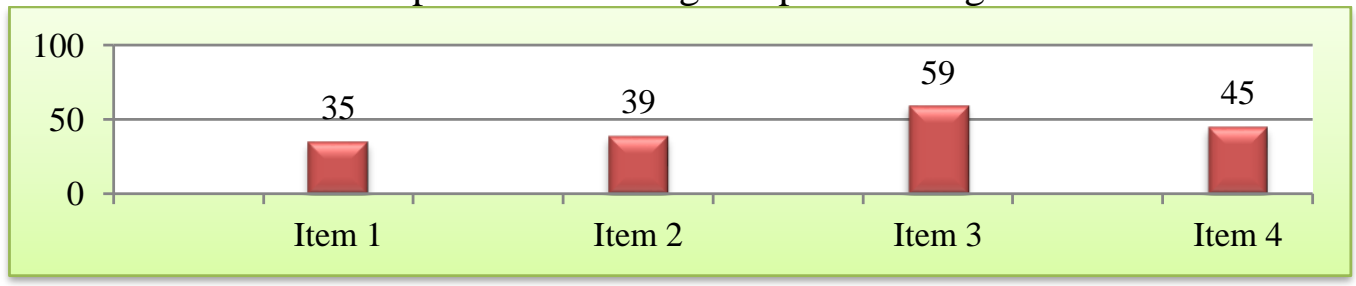

Berdasarkan Grafik 4 dapat dilihat bahwa nilai rata-rata peserta didik adalah $45 \%$, hal ini mengartikan bahwa peserta didik kurang baik dalam memaknakan memiliki kemampuan untuk menghadapi dan mengatasi rasa sakit. Item 1 menandai 35\% peserta didik selalu mencari solusi dari sebuah kesalahan, sering mengeluh dengan hidupnya, item 2 menandai 39\% peserta didik akan mencari kerja sendiri bila orang tuanya belum mampu memenuhi keperluannya, item 3 menandai bahwa 59\% peserta didik merasa tidak berdaya jika ditinggal pacar, dan item 4 menandai $45 \%$ peserta didik akan mencari penyebabnya, jika dimarahi guru. Dalam kata lain, bahwa peserta didik kurang baik (45\%) dalam memakani kemampuan untuk menghadapi dan mengatasi rasa sakit.

Grafik 5. Memiliki kualitas hidup yang diilhami oleh visi dan nilai-nilai.

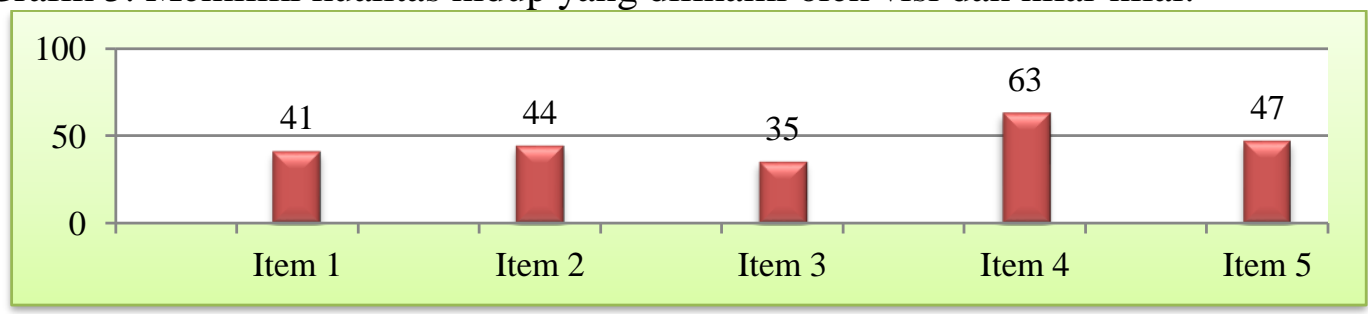

Berdasarkan Grafik 5 dapat dilihat bahwa nilai rata-rata peserta didik adalah 46\%, hal ini mengartikan bahwa peserta didik kurang baik dalam memaknakan memiliki 
kualitas hidup yang diilhami oleh visi dan nilai-nilai. Item 1 menandai $41 \%$ peserta didik tidak ingin acuh tak acuh dengan sekolanya, item 2 menandai $44 \%$ peserta didik selalu menggunakan waktu untuk melakukan hal-hal yang berguna, item 3 menandai bahwa $35 \%$ peserta didik ke sekolah bukan karena teman-temannya, item 4 menandai $63 \%$ peserta didik selalu memikirkan masa depannya, dan item 5 menandai $47 \%$ peserta didik ingin sekolah sesuai harapan keluarga. Dalam makna lain, bahwa begitupun dengan data kualitas hidup yang diilhami oleh visi dan nilai-nilai, peserta didik kurang baik (46\%) dalam memaknainya. Peserta didik sebagian besar acuh tak acuh dengan sekolanya, tidak efisien menggunakan waktu untuk melakukan hal-hal yang berguna, ke sekolah hanya karena teman-temannya

Grafik 6. Enggan melakukan sesuatu yang menyebabkan kerugian atau kerusakan

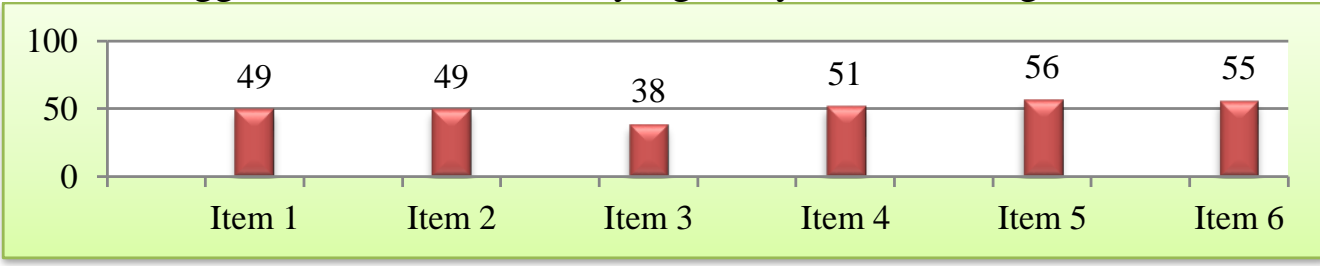

Berdasarkan Grafik 6, dapat dilihat bahwa nilai rata-rata peserta didik adalah 49\%, hal ini mengartikan bahwa peserta didik kurang baik dalam memaknakan enggan melakukan sesuatu yang menyebabkan kerugian atau kerusakan. Item 1 menandai 49\% peserta didik sering merasa akan berhenti sekolah, item 2 menandai $49 \%$ peserta didik selalu berusaha menjadi pribadi yang baik, item 3 menandai bahwa $38 \%$ peserta didik berusaha mengundang guru bila tiba waktu masuk kelas, item 4 menandai $51 \%$ peserta didik tidak mengadu domba teman, item 5 menandai $56 \%$ peserta didik sering berfoyafoya dan item 6 menandai 55\% peserta didik menjaga apa yang dimilikinya. Data ini menunjukkan bahwa peserta didik kurang baik (49\%) dalam memaknakan enggan melakukan sesuatu yang menyebabkan kerugian atau kerusakan. Peserta didik sering merasa akan berhenti sekolah, separuh peserta didik selalu berusaha menjadi pribadi yang baik, hanya sebagian peserta didik berusaha mengundang guru bila tiba waktu masuk kelas, separuh peserta didik mengadu domba teman dan sering berfoya-foya

Grafik 7. Cenderung melihat hubungan antar berbagai hal berbeda menjadi suatu yang holistik

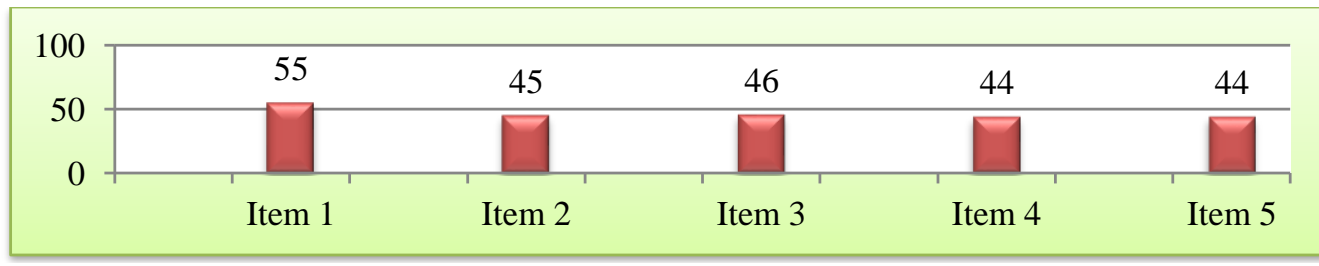

Berdasarkan Grafik 7, dapat dilihat bahwa nilai rata-rata peserta didik adalah 47\%. Hal ini mengartikan bahwa peserta didik kurang baik dalam memaknakan cenderung melihat hubungan antar berbagai hal berbeda menjadi suatu yang holistik. Item 1 menandai $55 \%$ peserta didik tidak suka bergaul dengan orang yang memiliki prestasi dibawahnya, item 2 menandai $45 \%$ peserta didik suka bergabung dengan teman dari daerah lain, item 3 menandai bahwa $46 \%$ peserta didik tidak ingin dinomor satukan dari saudara yang lain dikeluarga, item 4 menandai $44 \%$ peserta didik menyukai guru di sekolahnya, dan item 5 menandai $44 \%$ peserta didik suka berbeda pendapat dengan orang 


$\begin{array}{ll}\text { Volume } & : 06 \\ \text { Nomor } & : 02 \\ \text { Bulan } & : \text { Mei } \\ \text { Tahun } & : 2020 \\ \text { http } & : / / \text { ejurnal.pps.ung.ac.id/index.php/AKSARA/index }\end{array}$

lain, agar bisa menambah pengetahuan. Data ini menunjukkan bahwa begitupula dengan kemampuan memaknai cenderung melihat hubungan antar berbagai hal berbeda menjadi suatu yang holistik. Peserta didik kurang baik (47\%) memaknainya dalam kehidupan sehari-hari. Peserta didik tidak suka bergaul dengan orang yang memiliki prestasi dibawahnya, kurang suka bergabung dengan teman dari daerah lain, ingin dinomor satukan dari saudara yang lain dikeluarga, kurang menyukai guru di sekolahnya, dan kurang menyukai beda pendapat dengan orang lain agar bisa menambah pengetahuan

Grafik 8. Cenderung untuk bertanya "mengapa" atau "apa" dan mencari jawabanjawaban yang fundamental

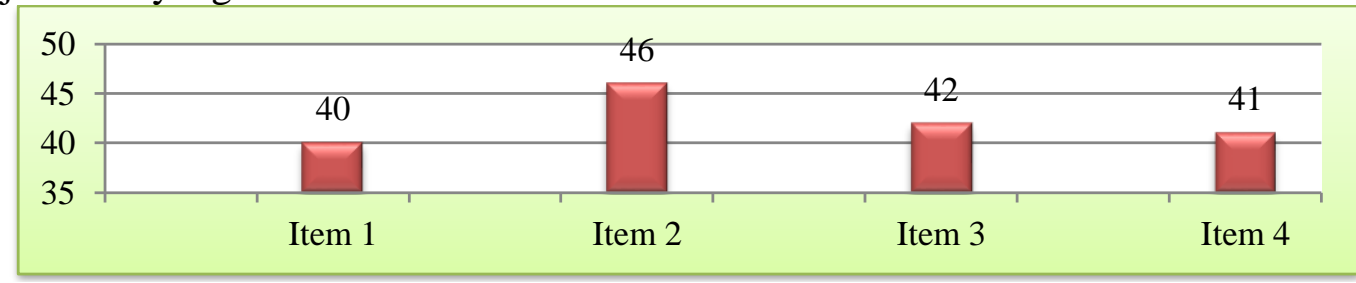

Berdasarkan Grafik 8 dapat dilihat bahwa nilai rata-rata peserta didik adalah $42 \%$. Hal ini mengartikan bahwa peserta didik kurang baik dalam memaknakan cenderung untuk bertanya "mengapa" atau "apa" dan mencari jawaban-jawaban yang fundamental. Item 1 menandai $40 \%$ peserta didik sudah memiliki rencana-rencana dimasa depan, item 2 menandai $46 \%$ peserta didik kurang memahami apa tujuan sekolah, item 3 menandai bahwa $42 \%$ peserta didik jika dimarahi, akan mencari tahu penyebab kesalahan, dan item 4 menandai $41 \%$ peserta didik sering bertengkar dengan teman tanpa alasan. Data ini juga menggambarkan bahwa kemampuan untuk bertanya "mengapa" atau "apa" dan mencari jawaban-jawaban yang fundamental, peserta didik kurang baik (42\%) dalam memaknainya. Peserta didik belum memiliki rencana-rencana dimasa depan, kurang memahami apa tujuan sekolah, dimarahi, tidak akan mencari tahu penyebab kesalahan, dan sering bertengkar dengan teman tanpa alasan.

Grafik 9. Bertanggungjawab untuk menebarkan visi dan nilai-nilai kepada orang lain dan menunjukkan cara menggunakan.

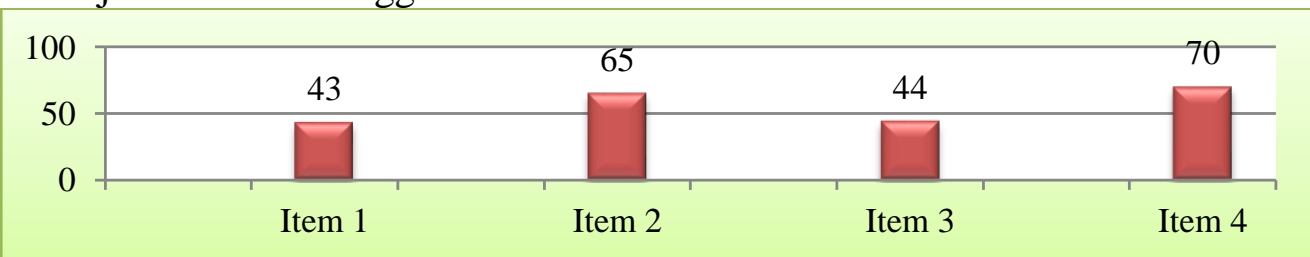

Berdasarkan Grafik 9 dapat dilihat bahwa nilai rata-rata peserta didik adalah $56 \%$. Hal ini mengartikan bahwa peserta didik cukup baik dalam bertanggungjawab untuk menebarkan visi dan nilai-nilai kepada orang lain dan menunjukkan cara menggunakan. Item 1 menandai $43 \%$ peserta didik selalu membagi pengalaman baik kepada orang lain, item 2 menandai $65 \%$ peserta didik suka memberi semangat pada teman yang mengalami kegagalan, item 3 menandai bahwa $44 \%$ peserta didik membatu teman jika mengalami kesulitan dalam belajar, dan item 4 menandai $70 \%$ peserta didik merasa sedih melihat teman gagal. Dalam arti lain bahwa, data ini sedikit berdeda dengan data sebelumnya. Peserta didik cukp baik (56\%) dalam bertanggungjawab untuk menebarkan visi dan nilainilai kepada orang lain dan menunjukkan cara menggunakan. Peserta didik selalu 
membagi pengalaman baik kepada orang lain, suka memberi semangat pada teman yang mengalami kegagalan, membatu teman jika mengalami kesulitan dalam belajar, dan merasa sedih melihat teman gagal.

Memaknai uraian tersebut di atas, maka penting meningkatkan kemampuan kecerdasan spiritual peserta didik dalam bentuk pembimbingan dengan mempertimbangkan dengan baik prinsip bimbingan, yakni (1) bimbingan dan konseling harus disesuaikan dengan pola pikir dan pemahaman peserta didik, (2) pelaksanaan bimbingan terintegrasi dengan pembelajaran, (3) mengatur waktu pelaksanaan, (4) pelaksanaan bimbingan dilaksanakan dalam nuansa menyenangkan, (5) adanya keterlibatan teman sebaya, dan (6) keterlibatan orang tua, (El Fiah, 2014;90). Selain itu perlu memperhatikan proses kesuksesan pelaksanaan konseling, dengan memperhatikan langkahlangkah yang disampaikan Zohar \& Marshall, (dalam Rahmawati, 2016;109) yang dapat diinternalisasikan dalam bentuk: (1) peserta didik harus menyadari di mana dirinya sekarang, (2) peserta didik merasakan dengan kuat bahwa dia ingin berubah, (3) peserta didik merenungkan apakah pusatnya sendiri dan apakah motivasinya yang paling dalam, (4) peserta didik menemukan dan mengatasi rintangan (5) menggali banyak kemungkinan untuk melangkah maju, (6) peserta diidk menetapkan hati pada sebuah jalan, (7) peserta didik melangkah di jalan yang dipilih sendiri, tetapi harus menyadari bahwa masih ada jala-jalan yang lain. Secara lebih luas, guna mengoptimalkan kecerdasan spiritual peserta didik, maka dapat dirancang optimalisasinya melalui manajemen peserta didik berbasis kecerdasan spiritual, yang meliputi: (1) perencanaan peserta didik, (2) penerimaan peserta didik baru, (3) orientasi peserta didik, (4) mengatur kehadiran dan ketidakhadiran peserta didik, (5) pengemlompokkan peserta didik, (6) mengatur evaluasi hasil belajar peserta didik, (7) mengatur kenaikan tingkat peserta didik, (8) mengatur peserta didik yang mutasi dan drop out, dan (9) kode etik, pengadilan, hukum dan disiplin peserta didik (Annas, 2017;136-137).

\section{KESIMPULAN}

Berdasarkan hasil penelitian dan pembahasan, dapat disimpulkan bahwa peserta didik kurang baik dalam memakanakan kecerdasan spiritual dalam kehidupan sehari-hari. Meliputi kurang baik memaknakan bersifat fleksibel, cukup baik dalam memaknakan memiliki kesadaran (self-awareness) yang tinggi, kurang baik dalam memaknakan kemampuan untuk menghadapi penderitaan dan mengambil hikmah darinya, kurang baik dalam memaknai kemampuan untuk menghadapi dan mengatasi rasa sakit, kurang baik memaknai memiliki kualitas hidup yang diilhami oleh visi dan nilai-nilai, kurang baik dalam memaknai enggan melakukan sesuatu yang menyebabkan kerugian atau kerusakan, kurang baik dalam memaknai cenderung melihat hubungan antar berbagai hal berbeda menjadi suatu yang holistik, kurang baik dalam memaknai cenderung untuk bertanya "mengapa" atau "apa" dan mencari jawaban-jawaban yang fundamental, dan cukup baik dalam bertanggungjawab untuk menebarkan visi dan nilai-nilai kepada orang lain dan menunjukkan cara menggunakan. Guna mengoptimalkan pemaknaan peserta didik dalam kecerdasan spiritual, dapat dilakukan melalui pendekatan bimbingan dan konseling, serta mengatur dalam bentuk manajemen peserta didik berbasis kecerdasan spiritual. 


$\begin{array}{ll}\text { Volume } & : 06 \\ \text { Nomor } & : 02 \\ \text { Bulan } & : \text { Mei } \\ \text { Tahun } & : 2020 \\ \text { http } & : / / \text { jurnal.pps.ung.ac.id/index.php/AKSARA/index }\end{array}$

\section{DAFTAR PUSTAKA}

Akhirin. 2013. Mengembangkan Kecerdasan Spiritual Melalui Rukun Iman dan Rukun Islam. Jurnal Tarbawi Vol.10, No.2, Juli-Desember 2013.

Al Haddar, Gamar. 2016. Upaya Pengembangan Kecerdasan Spiritual Siswa Melalui Kegiatan Ekstrakurikuler Rohani Islam di SMP Yapan Indonesia, Depok. Jurnal Pendas Mahakam, Vol. 1 (1), 42-53. Juni 2016

Amir, Yulmaida \& Diah Rini Lesmawati. 2016. Religiusitas dan Spiritualitas: Konsep Yang Sama Atau Berbeda? Jurnal Ilmiah Penelitian Psikologi: Kajian Empiris \& Non-Empiris Vol. 2., No. 2., 2016. Hal. 67-73.

Annas, Annisa Nuraisyah. 2017. Manajemen Peserta Didik Berbasis Kecerdasan Spiritual Pendidikan Islam. TADBIR : Jurnal Manajemen Pendidikan Islam Volume 5, Nomor 2: Agustus 2017.

Baharuddin. H \& Esa Nur Wahyuni. 2015. Teori Belajar dan Pembelajaran. Jakarta. Ar-Ruzz Media.

Basuki, Kasih Haryo. 2015. Pengaruh Kecerdasan Spiritual dan Motivasi Belajar terhadap Prestasi Belajar Matematika. Jurnal Formatif 5(2): 120-133, 2015.

Chin, Susan Tee Suan, R.N. Anantharaman \& David Yoon Kin Tong. 2011. The Roles of Emotional Intelligence and Spiritual Intelligence at the Workplace. Journal of Human Resources Management Research. Vol. 2011 (2011).

El Fiah, Rifda. 2014. Mengembangkan Potensi Kecerdasan Spiritual Anak Usia Dini Implikasi Bimbingannya KONSELI: Jurnal Bimbingan dan Konseling (EJournal). Volume: 01 (2); 2014; 85-92

Hagar. 2019. Pentingnya Kecerdasan Spiritual. dapat diakses di https://www.youngontop.com/read/19100/pentingnya-kecerdasan-spiritual/

Hera, Dea. 2017. Kecerdasan Spiritual Berpengaruh pada Kualitas Peserta Didik. Dapat diakses di www.kompas.com

Howard, Barbara B., Precious Guramatunhu-Mudiwa, \& Stephen R. White. 2009. Spiritual Intelligence and Transformational Leadership: A New Theoretical Framework. Journal of Curriculum and Instruction (JoCI), November 2009, Volume 3, Number 2,

Imaduddin, Aam. 2017. Spiritualitas dalam Konteks Konseling.Journal Of Innovative Counseling: Theory, Practice \& Research Vol.1, No.1, Januari 2017

Nisa, Khairun 2009. Hidden Curriculum; Upaya Peningkatan Kecerdasan Spiritual Siswa. Jurnal Lentera Pendidikan, Vol.12 No.1 Juni 2009.72-86

Rahman, Zanariah Abdul \& Shah, Ishak Md. 2015. Measuring Islamic Spiritual Intelligence. International Accounting and Business Conference 2015, IABC 2015. Procedia Economics and Finance 31 ( 2015) 134 139.www.elsevier.com

Rahmawati, Ulfa. 2016. Pengembangan Kecerdasan Spiritual santri: Studi terhadap Kegiatan Keagamaan di Rumah TahfizQu Deresan Putri Yogyakarta. Jurnal Penelitian, Vol. 10, No. 1, Februari 2016

Rampisela, Deisa Iriani., Sefti Rompas \& Reginus Malara. 2017. Hubungan Kecerdasan Emosional dan Kecerdasan Spiritual dengan Prestasi Belajar Siswa di SMP Katolik St. Fransiskus Pineleng. e-journal Keperawatan (e-Kp) Volume 5 Nomor 1, Februari 2017 